\title{
Cockle (Anadara granosa) Tolerance to Ammonia Exposed to Various Concentrations
}

\author{
Mohd Fadzil Shuhaimi bin Ramli ${ }^{1}$, Faizal Riza bin Abu Hassan ${ }^{2}$, Paveanthen \\ Ramachandran ${ }^{2}$ \\ ${ }^{l}$ Quest International University Perak, Jalan Raja Permaisuri Bainun, 30250 Ipoh, Perak, Malaysia \\ ${ }^{2}$ Universiti Selangor, Jalan Timur Tambahan, 45600 Bestari Jaya, Selangor, Malaysia.
}

\begin{abstract}
Cockles with sizes ranging from $30-38 \mathrm{~mm}$ were exposed to various concentrations of ammonia to determine the lethal limits of the organisms. In each rectangular plastic container, 5 liter of artificial sea-water was filled containing $0.0 \mathrm{mg} / \mathrm{L}, 0.1 \mathrm{mg} / \mathrm{L}, 0.2 \mathrm{mg}, 0.3 \mathrm{mg} / \mathrm{L}, 0.4 \mathrm{mg} / \mathrm{L}, 0.5 \mathrm{mg} / \mathrm{L}, 0.6 \mathrm{mg} / \mathrm{L}, 0.7 \mathrm{mg} / \mathrm{l}$ and $0.8 \mathrm{mg} / \mathrm{L}$ of total ammonia. The concentrations were prepared from the ammonia liquor containing $25 \%$ free ammonia. The temperature was at $29^{\circ} \mathrm{C}$ and salinity at 27 ppt and kept constant throughout the test. The water pH was noted between 8.3-8.5. With known temperature and $\mathrm{pH}$, the values of $\mathrm{NH}_{3}$ were calculated. Using SPSS's Probit analysis, the value of $\mathrm{LC}_{50}$ at $48-\mathrm{h}$ was $0.08 \mathrm{mg} / \mathrm{L}$ of $\mathrm{NH}_{3}$ whereas at $96-\mathrm{h}$, the value was $0.04 \mathrm{mg} / \mathrm{L}$. In the 48-h duration most cockles mortality occurred before the 32-h. The 100\% mortality occurred for cockles exposed to concentrations between $0.08 \mathrm{mg} / \mathrm{L}-0.13 \mathrm{mg} / \mathrm{L}$ before the $84-\mathrm{h}$. At $0.06 \mathrm{mg} / \mathrm{L}$ about $60 \%$ mortality was recorded at $92-h$ and the rest of the concentrations were $0.05 \mathrm{mg} / \mathrm{l}, 0.03$ and $0.02 \mathrm{mg} / \mathrm{L}$ with $30 \%, 23 \%$ and $20 \%$ mortality respectively. The $L C_{100}$ at $96-h$ and at 48 - $h$ exposure was $0.16 \mathrm{mg} / \mathrm{L}$ and $0.3 \mathrm{mg} / \mathrm{L}$ respectively.
\end{abstract}

Keywords: cockles, ammonia, tolerance, mortality, Probit analysis

\section{Introduction}

The in situ study on the relationship between ammonia concentrations and cockles (Anadara granosa, blood cockles) in Sg Buluh, Selangor farm areas recorded high ammonia concentration causing the declining production of cockles [1]. The common location of cockles farming areas were closed to the river mouth where upstream water discharged into the sea was mostly polluted by effluents from factories, farms, plantations, houses and towns. Between Kuala Selangor estuary and Sg Tambak Jawa estuary, there were 50 lots of cockles farm each measuring approximately 50 hectares of area. It was the project initiated by state government to increase cockles' productivity simultaneously providing opportunity for some fishermen to improve their livelihood [2]. At present, a total of 5,263 hectares of coastal land are being utilized as cockle farms in the state of Selangor [3]. Although the farm areas nationwide have been expanded in recent years, the production in term of per unit area showed a declining trend from year 2000 to 2010 indicating a significant environmental threat to cockles [4].

The ammonia contained in water is in the form of un-ionized ammonia $\mathrm{NH}_{3}$ (or simply $\mathrm{NH}_{3}$ ) and ammonium ions $\mathrm{NH}_{4}$ [5]. The combination of both $\mathrm{NH}_{3}$ and ammonium is commonly indicated as total ammonia which most methods of ammonia measurement are giving. The $\mathrm{NH}_{3}$ is the most toxic substance than the $\mathrm{NH}_{4}$ and its value increases with the increase in temperature and $\mathrm{pH}$ [6]. It is therefore a mandatory procedure to record the changes in temperature and $\mathrm{pH}$ if the interest is to find out the value of $\mathrm{NH}_{3}$.It can be obtained by using the Table 1.0 with known temperature and $\mathrm{pH}$ using the formula $\mathrm{NH}_{3}=$ total ammonia $\mathrm{x}$ percent un-ionized [7]. The $\mathrm{NH}_{3}$ is so toxic that at $0.02 \mathrm{mg} / \mathrm{L}$ it will kill some marine organisms [8].

The task to identify the main reason causing cockles declining production in Sg Buluh farm areas is challenging. Cockle depletion can be triggered by many factors such as pollutions [9], bad farm management [10] or predators [11] [12] [13]. Lately, it was found that most cockle beds are infertile and need to be replenished with fertilizers or detritus [14]. 
Table 1.0: Calculated from data in Emmerson et al [7].

\begin{tabular}{|c|c|c|c|c|c|c|c|c|c|c|c|c|c|c|}
\hline \multicolumn{15}{|c|}{ Temperature } \\
\hline \multirow{2}{*}{ pH } & $\begin{array}{l}42.0 \\
\left({ }^{\circ} \mathrm{F}\right)\end{array}$ & 46.4 & 50.0 & 53.6 & 57.2 & 60.8 & 64.4 & 68.0 & 71.6 & 75.2 & 78.8 & 82.4 & 86.0 & 89.6 \\
\hline & $\begin{array}{c}6 \\
\left({ }^{\circ} \mathrm{C}\right)\end{array}$ & 8 & 10 & 12 & 14 & 16 & 18 & 20 & 22 & 24 & 26 & 28 & 30 & 32 \\
\hline 7.0 & .0013 & .0016 & .0018 & .0022 & .0025 & .0029 & .0034 & .0039 & .0046 & .0052 & .0060 & .0069 & .0080 & .0093 \\
\hline 7.2 & .0021 & .0025 & .0029 & .0034 & .0040 & .0046 & .0054 & .0062 & .0072 & .0083 & .0096 & .0110 & .0126 & .0150 \\
\hline 7.4 & .0034 & .0040 & .0046 & .0054 & .0063 & .0073 & .0085 & .0098 & .0114 & .0131 & .0150 & .0173 & .0198 & .0236 \\
\hline 7.6 & .0053 & .0063 & .0073 & .0086 & .0100 & .0116 & .0134 & .0155 & .0179 & .0206 & .0236 & .0271 & .0310 & .0369 \\
\hline 7.8 & .0084 & .0099 & .0116 & .0135 & .0157 & .0182 & .0211 & .0244 & .0281 & .0322 & .0370 & .0423 & .0482 & .0572 \\
\hline 8.0 & .0133 & .0156 & .0182 & .0212 & .0247 & .0286 & .0330 & .0381 & .0438 & .0502 & .0574 & .0654 & .0743 & .0877 \\
\hline 8.2 & .0210 & .0245 & .0286 & .0332 & .0385 & .0445 & .0514 & .0590 & .0676 & .0772 & .0880 & .0998 & .1129 & .1322 \\
\hline 8.4 & .0328 & .0383 & .0445 & .0517 & .0597 & .0688 & .0790 & .0904 & .1031 & .1171 & .1326 & .1495 & .1678 & 1948 \\
\hline 8.6 & .0510 & .0593 & .0688 & .0795 & .0914 & .1048 & .1197 & .1361 & .1541 & .1737 & .1950 & .2178 & .2422 & .2768 \\
\hline 8.8 & .0785 & .0909 & .1048 & .1204 & 1376 & .1566 & .1773 & .1998 & .2241 & .2500 & .2774 & .3062 & .3362 & .3776 \\
\hline 9.0 & .1190 & .1368 & .1565 & .1782 & .2018 & .2273 & .2546 & .2836 & .3140 & .3456 & .3783 & .4116 & .4453 & .4902 \\
\hline 9.2 & .1763 & .2008 & .2273 & .2558 & .2861 & .3180 & .3512 & .3855 & .4204 & .4557 & .4909 & .5258 & .5599 & .6038 \\
\hline 9.4 & .2533 & .2847 & .3180 & .3526 & .3884 & .4249 & .4618 & .4985 & .5348 & .5702 & .6045 & .6373 & .6685 & .7072 \\
\hline 9.6 & .3496 & .3868 & .4249 & .4633 & .5016 & .5394 & .5762 & .6117 & .6456 & .6777 & .7078 & .7358 & .7617 & .7929 \\
\hline 9.8 & .4600 & .5000 & .5394 & .5778 & .6147 & 6499 & .6831 & .7140 & .7428 & .7692 & .7933 & .8153 & .8351 & .8585 \\
\hline 10.0 & .5745 & .6131 & .6498 & .6844 & .7166 & .7463 & .7735 & .7983 & .8207 & .8408 & .8588 & .8749 & .8892 & .9058 \\
\hline 10.2 & .6815 & .7152 & .7463 & .7746 & .8003 & .8234 & .8441 & .8625 & .8788 & .8933 & .9060 & .9173 & .9271 & .9389 \\
\hline
\end{tabular}

Pollution factors can be considered significant contributor towards cockles declining production since it is well known that $\mathrm{Sg}$ Buluh river is heavily polluted although less affected by heavy metals [15]. The ammonia concentration in Sg Buluh river was between $0.3 \mathrm{mg} / \mathrm{L}$ to $4 \mathrm{mg} / \mathrm{L}$ indicating the concentration had exceeded the cockle maximum tolerance level towards ammonia [1]. $\mathrm{NH}_{3}$ is always be associated with aquatic organisms slowed growth [16] [17], reduced reproduction [18] [19] or death [20]. In this laboratory study, live cockles were exposed to concentrations of ammonia ranging from $0.1 \mathrm{mg} / \mathrm{L}$ to $0.8 \mathrm{mg} / \mathrm{L}$ to determine its values at $\mathrm{LC}_{50}$ and $\mathrm{LC}_{100}$ at $48 \mathrm{-h}$ and 96-h durations. With known $\mathrm{pH}$ and temperature, the values of $\mathrm{NH}_{3}$ were calculated.

\section{Materials And Methods}

The artificial sea water at $27 \mathrm{ppt}$ was prepared by dissolving $4.2 \mathrm{~kg}$ of commercial sea salt in 140 liters of water. The various concentrations of ammonia for the test were prepared from the stock of $25 \%$ free ammonia solution and diluted to $10 \mathrm{mg} / \mathrm{L}$ of ammonia. The salicylate method was used to measure the ammonia using $\mathrm{HACH} \mathrm{DR} / 890$ colorimeter [21]. The dilution formula to obtain the required concentrations is thus, V1 = $\mathrm{V} 2 * \mathrm{M} 2 / \mathrm{M} 1$ where $\mathrm{M} 1$ is the initial concentration, V1 is the initial volume, M2 is the final concentration and V2 is the final volume [22]. The ammonia concentration for the controls was $0.0 \mathrm{mg} / \mathrm{L}$. In each replicate container, 30 healthy adult cockles with sizes ranging from $30 \mathrm{~mm}$ to $38 \mathrm{~mm}$ were used and well aerated. The test design is shown in Table 2.0 below.

Table 2.0: Test design

\begin{tabular}{llllll}
\hline $\begin{array}{l}\mathrm{V}_{1} \\
(\mathrm{ml})\end{array}$ & $\begin{array}{l}\text { Volume of } \\
\text { salt water } \\
\text { added } \\
(\mathrm{ml})\end{array}$ & $\begin{array}{l}\mathrm{V}_{2} \\
(\mathrm{ml})\end{array}$ & $\begin{array}{l}\mathrm{M}_{2} \\
(\mathrm{mg} / \mathrm{L})\end{array}$ & $\begin{array}{l}\text { Number of } \\
\text { replicates }\end{array}$ & $\begin{array}{l}\text { Number of } \\
\text { cockles in } \\
\text { each replicate }\end{array}$ \\
\hline 50 & 4950 & 5000 & 0.1 & 3 & 30 \\
\hline 100 & 4900 & 5000 & 0.2 & 3 & 30 \\
\hline 150 & 4850 & 5000 & 0.3 & 3 & 30 \\
\hline 200 & 4800 & 5000 & 0.4 & 3 & 30 \\
\hline 250 & 4750 & 5000 & 0.5 & 3 & 30 \\
\hline 300 & 4700 & 5000 & 0.6 & 3 & 30 \\
\hline 350 & 4650 & 5000 & 0.7 & 3 & 30 \\
\hline 00 & 4600 & 5000 & 0.8 & 3 & 30 \\
\hline
\end{tabular}

The duration of exposure to ammonia was 96 hours and observation recorded hourly. Cockles were not fed during the observation to reduce ammonia production/interference [23]. The death of the cockles was confirmed by its inability to close the valves upon mechanical stimulus such as touching it with glass rod [24] and immediately removed from the container. The essential water parameters such as $\mathrm{pH}$, dissolved oxygen, temperature and salinity were recorded and whenever possible kept constant. Suitable water parameters for cockles were referred; salinity $25-30 \mathrm{ppt}$ [25], temperature $25^{\circ} \mathrm{C}-32^{\circ} \mathrm{C}$ [12], $\mathrm{pH} 7.1-8.5$ [26] and oxygen above 7 $\mathrm{mg} / \mathrm{L}$ [27]. Probit analysis as in IBM SPSS Statistics 20 was performed to obtain the values of ammonia for $\mathrm{LC}_{50}$ and $\mathrm{LC}_{100}$ at $48-\mathrm{h}$ and $96-\mathrm{h}$. 


\section{Results And Discussion}

During the 96-h observation, the recorded $\mathrm{pH}$ values ranged from 8.3 to 8.5 , average dissolved oxygen was $7.9 \mathrm{mg} / \mathrm{L}$, temperature at $29^{\circ} \mathrm{C}$ and salinity at $27 \mathrm{ppt}$. For the estimation of $\mathrm{NH}_{3}$, the $\mathrm{pH}$ value was taken as an average value of 8.4. Using $\% \mathrm{NH}_{3}$ table as provided, at $29^{\circ} \mathrm{C}$ and $\mathrm{pH} 8.4$, the $\% \mathrm{NH}_{3}$ is 15.9. Fig. 1.0 shows the cumulative $\%$ of mortality against hourly observation and $\mathrm{NH}_{3}$ concentrations.

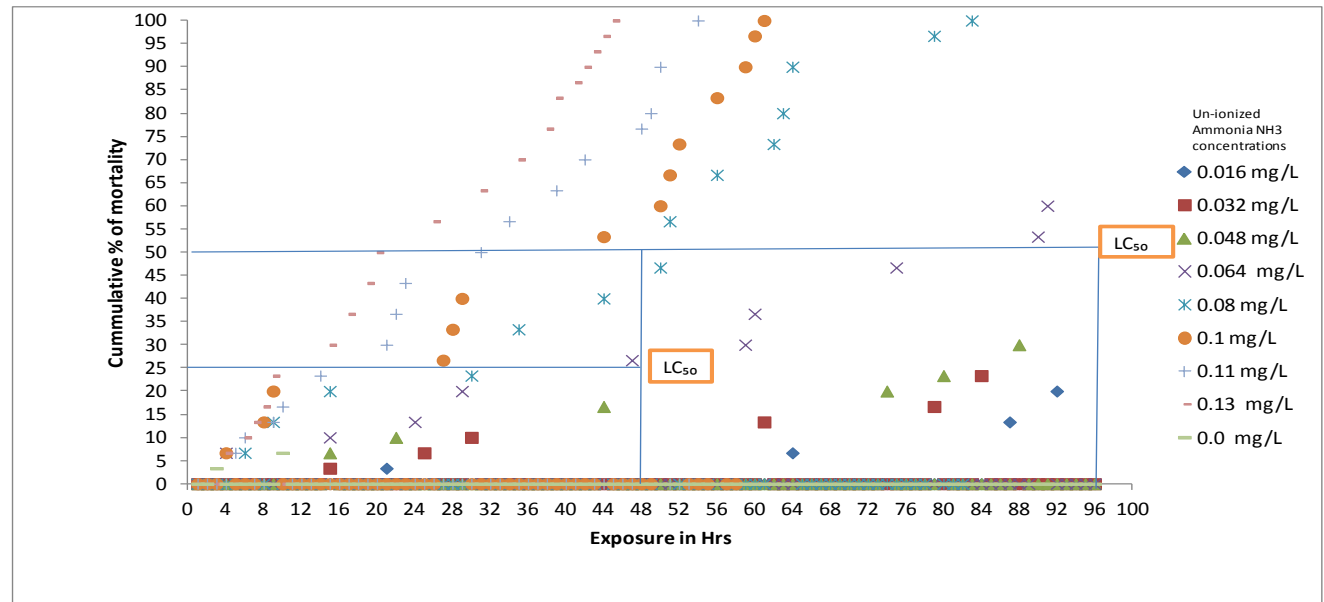

Figure 1.0: Cumulative cockles mortality exposed to various $\mathrm{NH}_{3}$ concentrations at $29^{\circ} \mathrm{C}$ and $\mathrm{pH} 8.4$

Using Probit analysis in the SPSS, the $\mathrm{LC}_{50}$ at 48 -h exposure was $0.08 \mathrm{mg} / \mathrm{L}$ of $\mathrm{NH}_{3}$ whereas at $96-\mathrm{h}$, the value was $0.04 \mathrm{mg} / \mathrm{L}$. In the 48 -h duration most cockles mortality occurred before the $32-\mathrm{h}$. The $100 \%$ mortality occurred for cockles exposed to concentrations between $0.08 \mathrm{mg} / \mathrm{L}-0.13 \mathrm{mg} / \mathrm{L}$ before the $84-\mathrm{h}$. At $0.06 \mathrm{mg} / \mathrm{L}$ about $60 \%$ mortality was recorded at $92-\mathrm{h}$ and the rest of the concentrations were $0.05 \mathrm{mg} / \mathrm{L}, 0.03$ $\mathrm{mg} / \mathrm{l}$ and $0.02 \mathrm{mg} / \mathrm{L}$ with $30 \%, 23 \%$ and $20 \%$ mortality respectively. The $\mathrm{LC}_{100}$ at $96-\mathrm{h}$ and at 48 -h exposure was $0.16 \mathrm{mg} / \mathrm{L}$ and $0.3 \mathrm{mg} / \mathrm{L}$ respectively.

The temperature of the coastal water of Kuala Selangor had been recorded between $29.21^{\circ} \mathrm{C}$ and $30.9^{\circ} \mathrm{C}$ and $\mathrm{pH}$ between 7.14 and 8.05 [28]. On the other hand, Ramli, Abu Hassan and Saadon [1] in their study on the cockles production in Sg Buluh (about $6.5 \mathrm{~nm}$ south of Kuala Selangor), had recorded the average ammonia between $0.3 \mathrm{mg} / \mathrm{L}$ and $4.0 \mathrm{mg} / \mathrm{L}$ during the months of January till June, 2013. If the temperature is taken as an average of $30^{\circ} \mathrm{C}$ and $\mathrm{pH} 7.7$, the lowest $\mathrm{NH}_{3}$ is estimated at $0.012 \mathrm{mg} / \mathrm{L}$ and the highest is $0.16 \mathrm{mg} / \mathrm{L}$ in the Selangor's waters. To illustrate the water quality status in relation to its uses, the Department of Environment Malaysia has published two standards; the Interim National Water Quality Standards (INWQS) which categorized river water into five classes based on the nutrient values (see Table 3.0 and Table 4.0) and Water Quality Index (WQI) which is an opinion-poll formula [29] summarizing water quality into three groups namely 'clean, slightly polluted and polluted' (see Table 5.0). With known total ammonia/un-ionized ammonia $\mathrm{NH}_{3}$ values of Selangor's water, it can be inferred that in general, the quality is in the poor state and with limited uses (see Table 6.0).Except in March (slightly polluted), the rest of the months were considered polluted with SIAN less than 41.

Table 3.0: Nutrient values found in river water quality classification system

\begin{tabular}{|c|c|c|c|c|c|c|}
\hline \multirow[t]{2}{*}{ Parameters } & \multirow[t]{2}{*}{ unit } & \multicolumn{5}{|c|}{ Water quality class } \\
\hline & & I & IIA & IIB & III & IV \\
\hline Ammonia & $\mathrm{mg} / \mathrm{L}$ & $<0.1$ & $0.1-0.3$ & $0.1-0.3$ & $0.3-0.9$ & $>2.7$ \\
\hline Nitrate & $\mathrm{mg} / \mathrm{L}$ & Natural Value & $<7.0$ & $<7.0$ & - & $<5.0$ \\
\hline Phosphate & $\mathrm{mg} / \mathrm{L}$ & Natural Value & $<0.2$ & $<0.2$ & $<0.1$ & - \\
\hline
\end{tabular}

Source: Department of Environment, Malaysia -River Water (Surface water) quality monitoring Programme, 2005 
Table 4.0: Classification of rivers Interim National Water Quality Standards (INWQS)

\begin{tabular}{lll}
\hline Class & Fuction & The level of water Treatment \\
\hline I & $\begin{array}{l}\text { Water supply for environmental conservation level I } \\
\text { Fishery I - very sensitive aquatic species }\end{array}$ & No Treatment Needed \\
IIA & $\begin{array}{l}\text { Water supply for environmental conservation level II } \\
\text { Fishery II - very sensitive aquatic species }\end{array}$ & Conventional water treatment is required \\
IIB & For recreational use & Conventional water treatment is required \\
III & $\begin{array}{l}\text { Water supply for environmental conservation level III } \\
\text { Fishery III- aquatic species commonly bred and have economic value, as well } \\
\text { as to serve as livestock drinking }\end{array}$ & extensive water treatment is required \\
& Irrigation & - \\
\hline
\end{tabular}

Source: Department of Environment -River Water (Surface water) quality monitoring Programme, 2005

Table 5.0: DOE Water Quality Classification

Based on Water Quality Index

\begin{tabular}{|lccc|}
\hline Parameters & & index Range & Polluted \\
\hline & Clean & Slightly Polluted & $0-79$ \\
\hline SIBOD & $91-100$ & $80-90$ & $0-70$ \\
\hline SIAN & $92-100$ & $71-91$ & $0-69$ \\
\hline SISS & $76-100$ & $70-75$ & $0-59$ \\
\hline WQI & $81-100$ & $60-80$ & 0 \\
\hline
\end{tabular}

Table 6.0: Un-ionized ammonia $\mathrm{NH}_{3}$ concentrations for months January till June 2013 in Sg Buluh (at average temperature $30^{\circ} \mathrm{C}$ and $\left.\mathrm{pH} 7.7\right)$

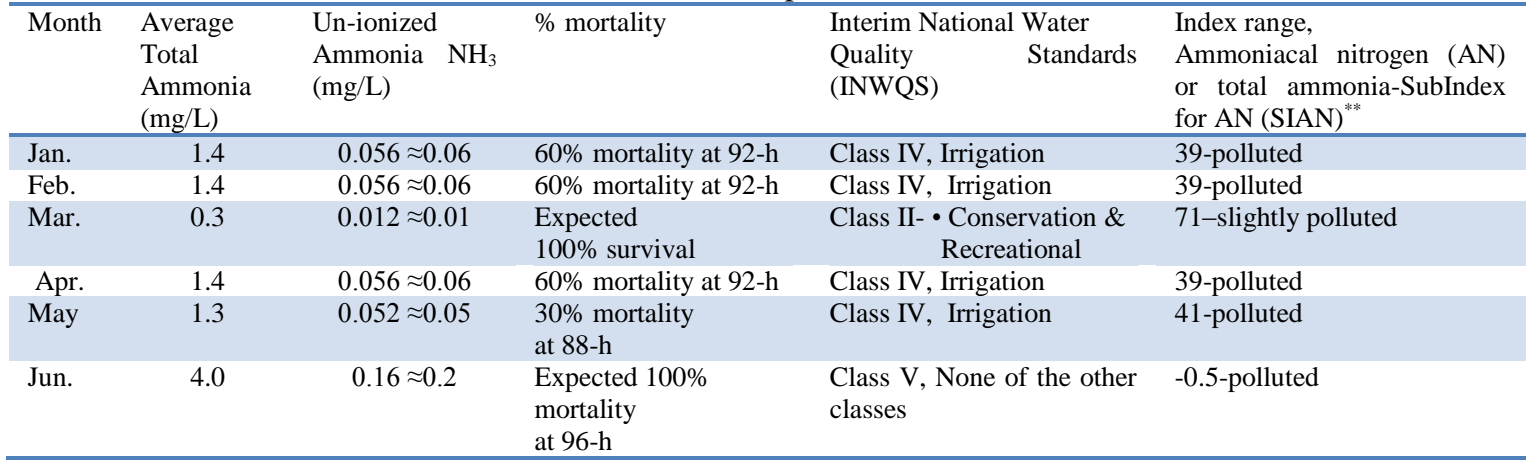

** Subindex for AN : SIAN

$100.5-105 \mathrm{x}$ for $\mathrm{x} \leq 0.3$

$94 \mathrm{e}-0.573 \mathrm{x}-5 \mathrm{x}-2$ for $0.3<\mathrm{x}<4$

The calculation of SIAN as in Zaki [30].

\section{Conclusion}

Water pollution in Malaysia is still a persistent problem although there are a handful of laws and regulation explicitly tailored to curb the perpetrators from polluting the environment. Unfortunately, major source of ammonia may come from the sewage treatment plants managed by Indah Water Consortium (IWK) [31], the government-owned company that its main responsibility is to ensure that wastewater is treated before being discharged into the rivers [32]. In early 2014, however, two major wastewater treatment plants in Selangor have been temporarily shut down due to high levels of ammonia in the discharged water [33]. Although the report did not specify the owner of those plants, it is believed that they belonged to IWK being the sole operator of the wastewater treatment plants in the state of Selangor. It is due time that a comprehensive study on the effect of allowable discharged ammonia to the water quality of rivers and sea to be carried out to determine new standard level that may be more tolerable to aquatic life. Currently, the water used to culture cockles in Selangor is under polluted category.

\section{Acknowledgment}

The author would like to thank the Dean of Faculty of integrative Sciences and Technology of Qiup International University Perak for the support and encouragement given during the preparation of the paper and the Universiti Selangor for the use of laboratory to conduct the research. 


\section{References}

[1]. M.F.S. Ramli, F.R. Abu Hasan, M.N. Saadon, "Declining Production of Cockles in Relation to Ammonia Concentrations in Sungai Buloh River, Selangor", Journal of Environment and Earth Science Vol. 3, No.10,pp. 1-5, 2013

[2]. Utusan "Kebun Online. kerang jana pendapatan”Utusan Available:http://www.utusan.com.my/utusan/Agrobiz/20130819/ag_01/Kebun-kerang-jana-pendapatan (23 May 2014)

[3]. Department of Fisheries Annual Statistics 2012. Available: http://www.dof.gov.my/c/document library/get file?uuid=f4a93474ee16-4e4f-b116-89cae8c7a258\&groupId=558715 (23 May 2014)

[4]. $\quad$ F.R Abu Hassan, M.F.S.Ramli and M.H. Abdullah. "Trend Perdagangan Industri Ternakan Kerang, Kupang dan Tiram di Malaysia Dari Tahun 2000 sehingga 2010”, Proceedings of International Conference on Multidisciplinary Research - ICMR 2012.

[5]. J. Camargo and A. Alonso. "Ecological and toxicological effects of inorganic nitrogen pollution in aquatic ecosystems: a global assessment", Environment International Vol. 32.,pp.831-849. 2006

[6]. C. E. Boyd (2013), “Ammonia Toxicity Degrades", Animal Health, Growth, global aquaculture advocate, November/December 2013, pp 40-43

[7]. K. Emerson, R.C. Russo, R.E. Lund, and R.V. Thurston. "Aqueous Ammonia Equilibrium Calculations: Effects of pH and Temperature", Journal of the Fisheries Research Board of Canada Vol. 32, pp. 2379-2383, 1975.

[8]. U.S. EPA ,. "U.S. Environmental Protection Agency, Washington DC”. EPA-822-R-99-014. 153 pp, (1999)

[9]. P. Dahiya and M. Ahlawat, Environmental Science: A New Approach,Alpha Science International, Limited, 2013 -

[10]. L. Shamsudin. Akuakultur Pinggir Pantai. Dewan Bahasa Dan Pustaka:Kuala Lumpur, 1992.

[11]. [T.Toyo, , I. Tesuji, N. Inoue. "The mass culture of ark shell, Anadara and their problems in Yamaguchi Prefecture". Cult. Res. 7:51-66, 1978

[12]. M.J. Broom M.J. "The biology and culture of marine bivalve of Genus Anadara”, ICLARM Studies and Review,pp.12:37, 1985

[13]. S. Tookwinas, "Cockle farming in Thailand. National Institute of Coastal Aquaculture", Division of Brackishwater, Department of Fisheries, Ministry of Agriculture and cooperative, Bangkok, Thailand, pp. 146, 1985

[14]. M.F.S. Ramli, and F.R. Abu Hasan, "Feeding cockles with detritus balls", IISTE Journal of Biology, Agriculture and Healthcare, vol.3, No.13, pp 102-107, 2013

[15]. K. Nemati, N.K.A. Bakar, M.R. Abas \& E. Sobhanzadeh, E. "Speciation of heavy metals by modified BCR sequential extraction procedure in different depths of sediments from Sungai Buloh, Selangor, Malaysia”. Journal of hazardous materials, 192(1), 402410, 2011

[16]. J. O. Harris,G.B. Maguire,S. Edwards,S. M. Hindrum. "Effect of ammonia on the growth rate and oxygen consumption of juvenile greenlip abalone,Haliotis laevigata Donovan”, Aquaculture, Volume 160, Issues 3-4, , Pages 259-272, 30 January 1998

[17]. Zafar Iqbal, Nasreen Ijaz, Jamil Anwar Chaudhry, “Effects of ammonia on growth of fingerlings of a freshwater fish, Cirrhinus mrigala (HamilZton)", European Journal of Veterinary Medicine, Vol 2, No 3 (2013), 163-170

[18]. [C.W. Hickey and M.L.Martin, "Chronic toxicity of ammonia to the freshwater bivalve Sphaerium novaezelandiae", Arch Environ Contam Toxicol.36(1):pp. 38-46, Jan 1999

[19]. R. Gergs, L. Schlag, K. O. Rothhaupt. "Different ammonia tolerances may facilitate spatial coexistence of Gammarus roeselii and the strong invader Dikerogammarus villosus", Biological Invasions,Volume 15,Issue 8,pp 1783-1793, August 2013.

[20]. C.D. Becker and T.O. Thatcher, "Toxicity of power plant chemicals to aquatic life", U.S. Atomic Energy Commission Publ., 1249, $1-218,1973$

[21]. M. Mokhtar, I. Bahari, Y. Chee \& A. Poon. "Kajian kualiti air di sekitar kawasan perindustrian Subang Jaya dan Shah Alam, Lembah Kelang”. Malaysia Journal of Analytical Science, 7 (1) : pp139-149, 2001

[22]. M. Silberberg, Chemistry: The Molecular Nature of Matter and Change, McGraw-Hill Higher Education, Dec 1, 2004

[23]. S. Barrento, I. Lupatsch ,A. Keay and G. Christophersen . "Metabolic rate of blue mussels (Mytilus edulis) under varying postharvest holding conditions", Aquat. Living Resour. Volume 26, pp 241-247, 2013

[24]. N. A. Reddy and N. R. Menon. "Effects of Ammonia and Ammonium on Tolerance and Byssogenesis in Perna viridis”, Mar. Ecol. Prog. Ser., Vol. 1,315321, 1979

[25]. B. Tiensongrusmee \& S. Ponjoprawira. Cockle culture. FAO Corporate Document Repository, INS/81/008/MANUAL/ 12 May 1988 Published by FAO Dept. of Fisheries and Aquaculture , 1988

[26]. N. F. Oon . "Growth and mortality of the Malaysian cockle (Anadara granosa) undercommercial culture: analysis through lengthfrequency data", Bay of Bengal programme BOBP/wp/47development of small-scale fisheries Food And Agriculture Organization of the United Nations GC P1RAS/040/SWE, 1986

[27]. K.C.A. Jalal et al. "Bacterial pollution in molluscs arch clam, Orbicularia orbiculata and blood cockle, Anadara granosa of Pahang estuary”, Malaysia.Journal of Biological Sciences, 99: pp 841-850, 2009

[28]. C. R. Mohamed and T. C. Siang, "Seasonal variation of ${ }^{210}$ Po in different salinity: Case study of Kuala Selangor river, west coast Peninsular Malaysia”, Coastal Marine Science 34(1): pp.186-194, 2010

[29]. Department of Environment Malaysia, "Development of Water Quality Criteria and Standards for Malaysia", 1985

[30]. Z. Zaki, "Benchmarking river water quality in Malaysia". Jurutera. pp. 12-15. , 2010

[31]. Department of Environment Malaysia, "Malaysia environmental quality report 2007. Environmental quality report, 86p", Department of Environment, Ministry of Natural Resources and Environment Malaysia, 2008.

[32]. Indah Water Consortium. Available: http://www.iwk.com.my/v/corporate-profile/corporate-profile (20 May 2014)

[33]. The Star, published: Wednesday February 12, 2014Available : http://www.thestar.com.my/News/Nation/2014/02/12/selangorwater-plant-ammonia/(20 May 2014) 